\title{
$\beta$-Estradiol Enhanced Secretion of Lipoprotein Lipase from Mouse Mammary Tumor FM3A Cells
}

\author{
Tomoyasu Fujii, ${ }^{* a}$ Mizuho Ogasawara, ${ }^{a, b}$ Jun Kamishikiryo, ${ }^{a}$ and Tetsuo Morita*, \\ ${ }^{a}$ Department of Biochemistry, Faculty of Pharmacy and Pharmaceutical Sciences, Fukuyama University; \\ 985 Higashimura, Fukuyama, Hiroshima 729-0292, Japan: and ${ }^{b}$ Department of Pharmacy, \\ Kochi Health Sciences Center; 2125-1 Ike, Kochi 781-8555, Japan. \\ Received May 11, 2020; accepted June 24, 2020
}

The role of $\beta$-estradiol $\left(\mathrm{E}_{2}\right)$ in lipoprotein metabolism in mammary tumors is unclear, therefore, we investigated the effect of $E_{2}$ on the secretion of lipoprotein lipase (LPL) from mouse mammary tumor FM3A cells. $E_{2}$-treated cells increased the secretion of active LPL from FM3A cells in a time- and dose-dependent manner. Activity of mitogen-activated protein kinase (MAPK) was increased in the tumor cells treated with $E_{2}$, and enhanced secretion of LPL was suppressed by MAPK kinase 1/2 inhibitor, PD98059, extracellular signal-regulated kinase (ERK) 1/2 inhibitor, FR180204, p38 MAPK inhibitor, SB202190, and phosphatidyl inositol 3-kinase (PI3K) inhibitor, LY294002. In addition, the effect of $E_{2}$ on LPL secretion was markedly suppressed by an inhibitor of mammalian target of rapamycin complex (mTORC) 1 and 2, KU0063794, but were not by a mTORC1 inhibitor, rapamycin. Furthermore, a small interfering RNA (siRNA)-mediated decrease in the expression of rapamycin-insensitive companion of mTOR (Rictor), a pivotal component of mTORC2, suppressed secretion of LPL by $E_{2}$. These results suggest that the stimulatory secretion of LPL by $E_{2}$ from the tumor cells is closely associated with an activation of $m$ TORC2 rather than mTORC1 possibly via the MAPK cascade.

Key words lipoprotein lipase; $\beta$-estradiol; mammary tumor; mitogen activated-protein kinase; mammalian target of rapamycin

\section{INTRODUCTION}

Breast cancer is one of the most serious cancers in women. ${ }^{1)}$ Epidemiological evidence indicates that elevated endogenous estrogen levels are associated with an increase in breast cancer in postmenopausal women. ${ }^{2-4)}$ In addition, the risk of breast cancer is linked to increases in estrogen level due to obesity. ${ }^{5-7)}$ Estrogen is known to affect nutrient supply by regulating the expression and activities of various enzymes involved in metabolic pathways, and the signal transduction and transcriptional actions of estrogen are also believed to contribute to the growth of cancer cells. ${ }^{8)}$ Furthermore, the role of lipids on the supply of the energy and cell components are particularly important in tumor growth and proliferation ${ }^{9,10)}$; however, the function of $\beta$-estradiol $\left(\mathrm{E}_{2}\right)$ on lipid metabolism in cancer cells is not fully understood.

Lipoprotein lipase (LPL) is responsible for supplying energy sources and cell components in lipid metabolism ${ }^{11)}$; LPL is synthesized in extrahepatic tissues ${ }^{12,13)}$ and adheres to cell surfaces and to the luminal endothelium of blood vessels. ${ }^{14)}$ Triacylglycerol components in chylomicron and very lowdensity lipoproteins in plasma are hydrolyzed by LPL, and the intracellular absorption of free fatty acids and the chylomicron remnants and intermediate-density lipoproteins is markedly dependent on LPL activities. ${ }^{11)}$

The effects of $E_{2}$ on lipoprotein metabolism are not well understood with regards to regulation of LPL from mammary tumor cells. In this study, we investigated the enhanced secretion of LPL from mouse mammary tumor FM3A cells by $\mathrm{E}_{2}$, and the association on the stimulation of LPL with the mammalian target of rapamycin (mTOR) pathway.

\section{MATERIALS AND METHODS}

Materials Chemicals were sourced as follows: Mouse mammary tumor FM3A cells (RIKEN Bio Resource Center, Tsukuba, Japan); $\beta$-estradiol (FUJIFILM Wako Pure Chemical Corporation, Osaka, Japan); PD98059, FR180204, SB202190, SP600125, LY294002, rapamycin, and KU0063794 (Funakoshi Co., Ltd., Tokyo, Japan); RPMI 1640 medium (Nippon Suisan Kaisha, Ltd., Tokyo, Japan); triolein [carboxyl$\left.{ }^{14} \mathrm{C}\right]-(3.7 \mathrm{MBq} / \mathrm{mL})$ and adenosine 5 -triphosphate $\left[\gamma_{-}{ }^{32} \mathrm{P}\right]-$ (370 MBq/mL) (PerkinElmer, Inc., MA, U.S.A.); anti-LPL antibody (LabFrontier, Seodaemun-gu, Seoul, Korea); antiRictor (53A2) antibody (Cell Signaling Technology, Inc., Beverly, MA, U.S.A.); anti- $\beta$-actin antibody (Proteintech, Tokyo, Japan); anti-rabbit secondary antibodies conjugated with horseradish (Bio-Rad, Hercules, CA, U.S.A.); goat anti-mouse immunoglobulin G (IgG)-heavy and light chain antibody horseradish peroxidase (HRP) conjugated (Bethyl Laboratories, Inc., Montgomery, AL, U.S.A.). All other chemicals used were of analytical grade.

Cell Culture Mouse mammary tumor FM3A cells were cultured in RPMI 1640 containing 10\% fetal bovine serum, $0.2 \mathrm{mM}$ alanine, $0.15 \mathrm{mM}$ kanamycin, $2 \mathrm{mM}$ glutamine, and $1 \mathrm{mM}$ sodium pyruvate under a humidified atmosphere at $37^{\circ} \mathrm{C}$ and $5 \% \mathrm{CO}_{2}$. Medium was removed by aspiration following centrifugation $\left(150 \times \boldsymbol{g}, 3 \mathrm{~min}\right.$ at $\left.4^{\circ} \mathrm{C}\right)$ and cells were seeded at a density of $1 \times 10^{7}$ cells $/ \mathrm{mL}$ in $\operatorname{HBSS}(+)$ without phenol red (FUJIFILM Wako Pure Chemical Corporation). Tumor cells were incubated with $\mathrm{E}_{2}$ in the presence of various inhibitors. After incubation, suspension cells were centrifuged $\left(860 \times \boldsymbol{g}, 3 \mathrm{~min}\right.$ at $\left.4^{\circ} \mathrm{C}\right)$. The supernatant was used as sample 

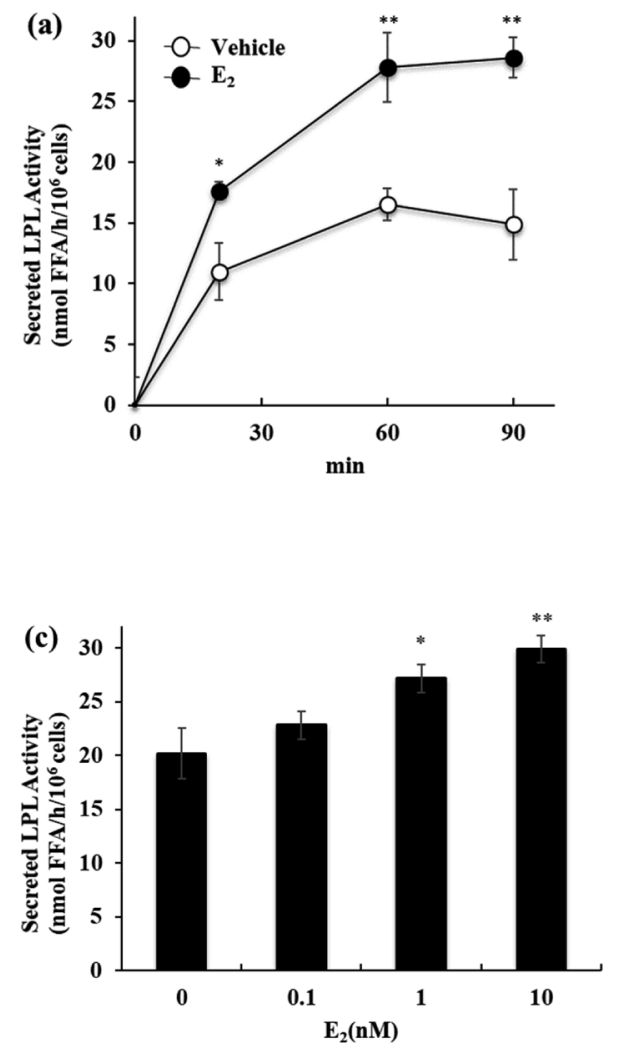
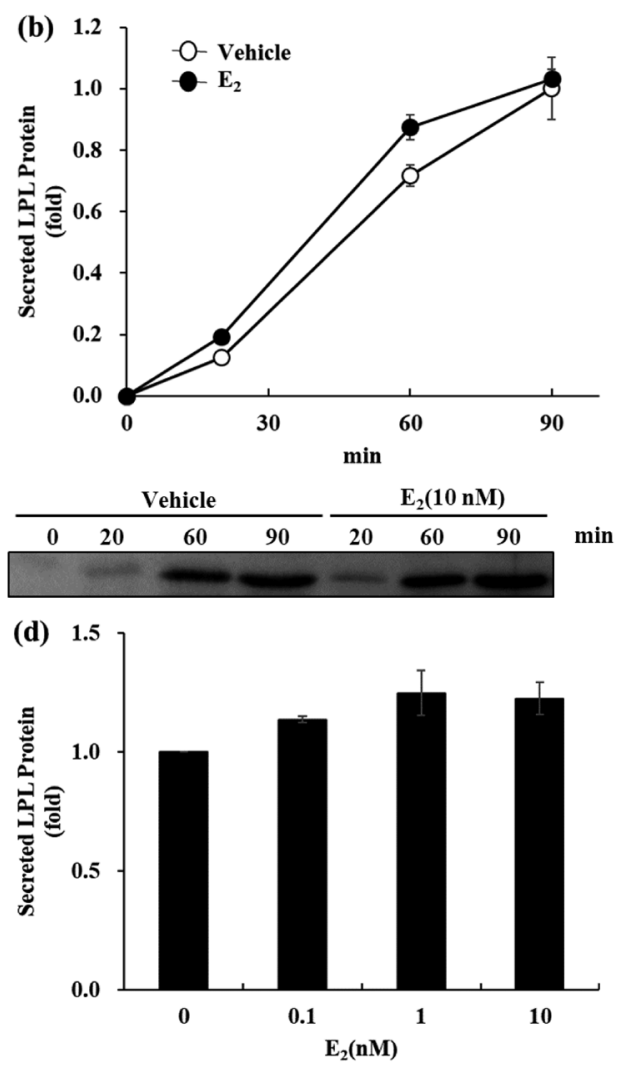

$\begin{array}{llll}0 & 0.1 & 1 & 10 \mathrm{E}_{2}(\mathrm{nM})\end{array}$

Fig. 1. Stimulatory Effects of $\beta$-Estradiol on Secretion of LPL Activity from Mouse Mammary Tumor FM3A Cells

FM3A cells were incubated for 60 min with $(\bullet) 10 \mathrm{nM} \mathrm{E}_{2}$ or without $(\bigcirc)$ for indicated time $(\mathrm{a}, \mathrm{b})$. Changes on secretion of LPL the cells incubated for 60 min with various concentrations of $\mathrm{E}_{2}(\mathrm{c}, \mathrm{d})$. The activity $(\mathrm{a}, \mathrm{c})$ and protein $(\mathrm{b}, \mathrm{d})$ of LPL secreted into the medium was measured as described in Materials and Methods. ${ }^{*} p<0.05$ and ** $p<0.01$, compared with groups without $\mathrm{E}_{2}$.

containing secreted LPL, and cells were used as sample for intracellular mitogen-activated protein kinase (MAPK) and LPL. Cells were sonicated with homogenate buffer $(25 \mathrm{mM}$ 4-(2-hydroxyethyl)-1-piperazineethanesulfonic acid (HEPES) [pH 7.2], $210 \mathrm{mM}$ mannitol, $70 \mathrm{mM}$ sucrose, $1 \mathrm{mM}$ ethylene glycol bis(2-aminoethyl ether)- $N, N, N^{\prime}, N^{\prime}$-tetraacetic acid (EGTA)), $5 \mu \mathrm{g} / \mathrm{mL}$ leupeptin, $1 \mathrm{mM} \beta$-glycerophosphate and $1 \mathrm{mM}$ sodium pyrophosphate. Cellular debris was removed by centrifugation $\left(16000 \times \boldsymbol{g} 10 \mathrm{~min}\right.$ at $\left.4^{\circ} \mathrm{C}\right)$ and processed for further experiments.

Determination of LPL Activity LPL activity was determined by a radioisotopic method using triolein [carboxyl $-{ }^{14} \mathrm{C}$ ]substrate. ${ }^{15)}$ The liberated ${ }^{14} \mathrm{C}$-fatty acids were separated from the reaction mixture. ${ }^{16)}$ LPL activity was determined by subtracting the non-LPL-dependent activity from the total lipolytic activity and expressed as nmol of free fatty acids (FFA) produced $/ \mathrm{h} / 10^{6}$ cells.

Determination of MAPK Activity MAPK activity was determined by modification of the published method. ${ }^{17}$ ) Enzyme solutions were incubated in $80 \mathrm{mM}$ Tris buffer $(\mathrm{pH}$ 7.5), $0.5 \mathrm{mg} / \mathrm{mL}$ myelin-basic protein (Sigma, St. Louis, MO, U.S.A.), $10 \mathrm{mM} \mathrm{MgCl}_{2}, 1 \mathrm{mM} \mathrm{MnCl}_{2}, 0.2 \mathrm{mM}$ ATP, adenosine $5^{\prime}$-triphosphate $\left.\left[\gamma^{32} \mathrm{P}\right]-\right)$ at $25^{\circ} \mathrm{C}$ for $20 \mathrm{~min}$. The reaction was stopped by adding $0.1 \mathrm{~N} \mathrm{HCl}$ containing $1 \mathrm{mg} / \mathrm{mL}$ bovine serum albumin (BSA). The phosphorylated substrate was applied to Whatman cellulose chromatography paper P81 and washed with $0.5 \%(\mathrm{v} / \mathrm{v})$ phosphoric acid. The paper strips were dried and analyzed for their radioactivity. The MAPK activity was expressed pmol of $\left[{ }^{32} \mathrm{P}\right]$ phosphorylated myelin $/ \mathrm{min} / 10^{6}$ cells.

Suppression of Rictor Expression FM3A cells, which were seeded at a density of $8 \times 10^{4}$ cells $/ \mathrm{mL}$, were transfected with $10 \mathrm{nM}$ small interfering RNA (siRNA) targeting mouse Rictor (SASI_Mm01_00137729, Sigma) or siRNA control (MISSION siRNA Universal Negative Control \#1, Sigma) using Lipofectamine RNAiMAX transfection reagent (Invitrogen, Waltham, MA, U.S.A.) and Opti-MEM (Gibco, Waltham, MA, U.S.A.). After the incubation, knock-down efficiency of transfection was confirmed by Western blotting.

Western Blotting Cell culture supernatant was used for protein quantification directly, and protein concentrations were determined by bicinchoninic acid (BCA) protein assay method. Five to twenty micrograms of total proteins were loaded in $10 \%(\mathrm{w} / \mathrm{v})$ sodium dodecyl sulfate (SDS) polyacrylamide gels and transferred to polyvinylidene difluoride (PVDF) membrane. After transfer, the membrane was blocked in $1 \%$ skim milk in TBS-T $(20 \mathrm{mM}$ Tris-buffer containing $137 \mathrm{mM} \mathrm{NaCl}, 1 \%(\mathrm{v} / \mathrm{v})$ Tween 20) for $1 \mathrm{~h}$ at room temperature and incubated with various primary antibodies diluted in TBS-T containing skim milk overnight at $4^{\circ} \mathrm{C}$. The membrane was washed in TBS-T and then incubated with the horseradish peroxidase-conjugated secondary antibody 
for $1 \mathrm{~h}$ at room temperature. The blots were visualized by using Western blot chemiluminescence reagent (ImmunoStar, FUJIFILM Wako Pure Chemical Corporation).

Statistical Analysis All results are presented as mean \pm standard error (S.E.) of six observations. Similar results were obtained with at least two separate experiments. The data were analyzed by Student's $t$-test.

\section{RESULTS}

Effect of $\mathbf{E}_{2}$ on Secretion of LPL Figure 1(a) shows the time-dependent secretion of LPL activity from FM3A cells

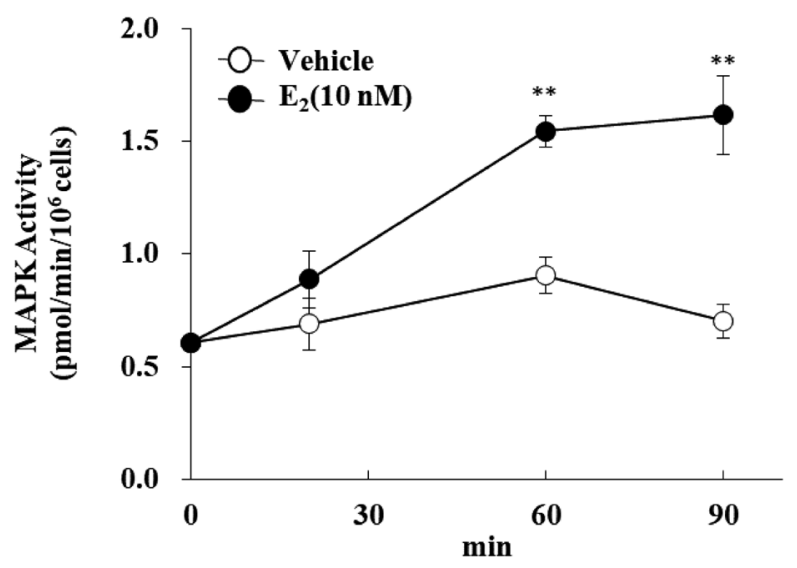

Fig. 2. Effects of $E_{2}$ on MAPK Activity in FM3A Cells

FM3A cells were incubated with $(\circlearrowleft) 10 \mathrm{nM} \mathrm{E}_{2}$ or without $(\bigcirc)$ over 90-min period. MAPK activity was measured as described in Materials and Methods. $* * p<0.01$, compared with groups without $\mathrm{E}_{2}$.
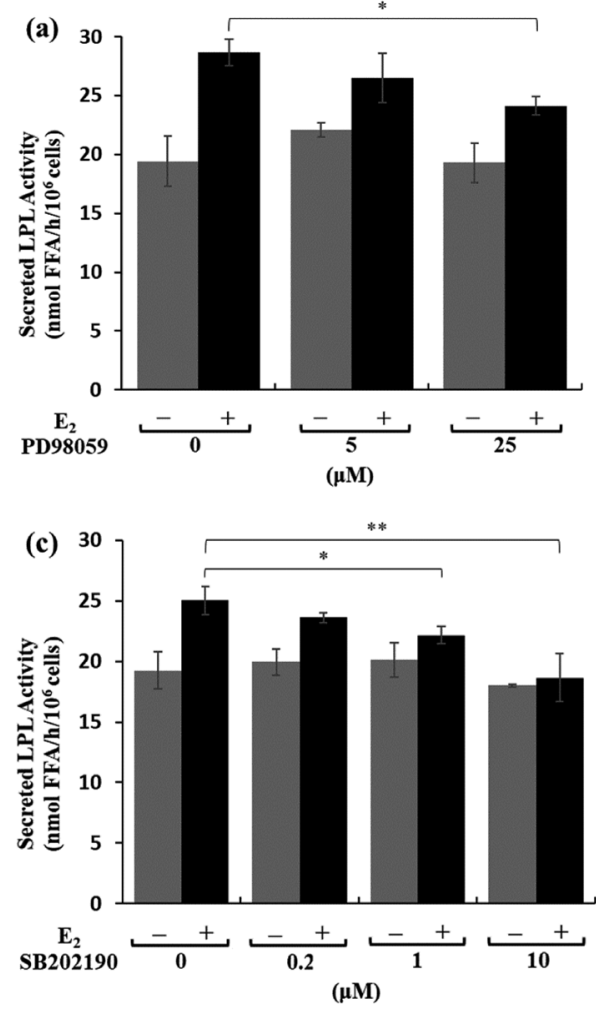

incubated with $10 \mathrm{nM} \mathrm{E_{2 }}$ over a 90-min period. Secreted LPL activity was 1.5 - to 2-fold higher than that of vehicle at $60 \mathrm{~min}$. However, the amount of LPL protein secreted into the medium was not found to change compared to vehicle (Fig. 1b). Cells were then incubated with $\mathrm{E}_{2}(0-10 \mathrm{nM})$ for $60 \mathrm{~min}$, which significantly enhanced the secretion of LPL activity in a dose-dependent manner up to $10 \mathrm{nM}(p<0.01)$ (Fig. 1c). The amount of LPL protein secreted into the medium was also not dose-dependent (Fig. 1d). These results suggested increases in specific activity of secreted LPL by $\mathrm{E}_{2}$. When $\mathrm{E}_{2}$ enhanced the secretion of LPL from the cells into the medium, the enzyme activity in the cells decreased (data not shown).

Effect of $\mathbf{E}_{\mathbf{2}}$ on Intracellular MAPK Activity $E_{2}$ is known to phosphorylate MAPK. ${ }^{18,19)}$ Therefore, to determine whether the stimulatory secretion of LPL activity by $E_{2}$ is involved in MAPK phosphorylation. Intracellular MAPK activity significantly increased with $\mathrm{E}_{2}$ supplementation in a time-dependent manner ( $p<0.01$ at $90 \mathrm{~min}$ ) (Fig. 2).

Effects of Various Inhibitor on Stimulatory Secretion of LPL by $\mathbf{E}_{2}$ Cells were incubated with $E_{2}$ in the presence of a various inhibitors of the MAPK cascade pathway. The stimulatory secretion of LPL by $E_{2}$ was suppressed by MAPK kinase 1/2 inhibitor, PD98059, extracellular signal-regulated kinase (ERK) 1/2 inhibitor, FR180204, p38 MAPK inhibitor, SB202190 (Figs. 3a-c), but not by a c-Jun N-terminal kinase (JNK) inhibitor, SP600125 (Fig. 3d). To examine the association of phosphatidyl inositol 3-kinase (PI3K) on $\mathrm{E}_{2}$-enhanced secretion of LPL, cells were incubated with $\mathrm{E}_{2}$ in the presence of a PI3K inhibitor, LY294002, which significantly reduced the $\mathrm{E}_{2}$-enhanced secretion at $10 \mu \mathrm{M}(p<0.01)$ (Fig. 4).

In addition, we investigated the effects of mammalian target
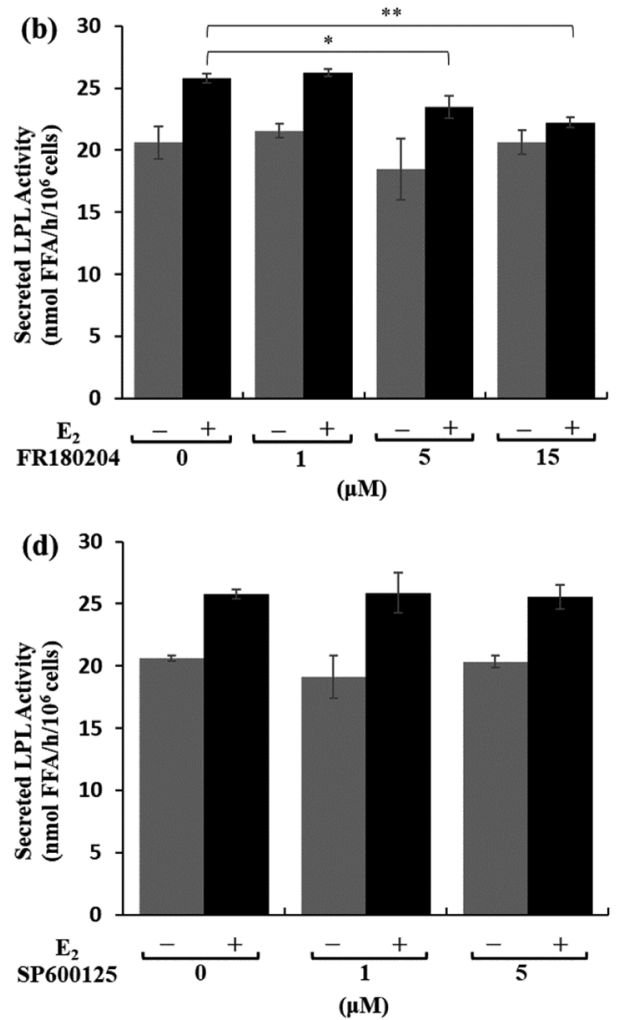

Fig. 3. Effects of MAPK Inhibitor on Stimulatory Secretion of LPL by $E_{2}$

FM3A cells were incubated for 60 min with $10 \mathrm{nM} \mathrm{E}_{2}$ or without in presence of PD98059 (a), FR180204 (b), SB202190 (c), SP600125 (d). The activity of LPL secreted into the medium was measured as described in Materials and Methods $\left({ }^{*} p<0.05,{ }^{*} p<0.01\right)$. 
of rapamycin (mTOR) inhibitors on the secretion of LPL by $\mathrm{E}_{2}$. The $\mathrm{E}_{2}$-enhanced secretion of LPL was markedly reduced by an mTORC1/2 inhibitor, KU0063794 (Fig. 5a) $(p<0.01$, $100 \mathrm{nM})$, but was not suppressed by an mTORC1 inhibitor,

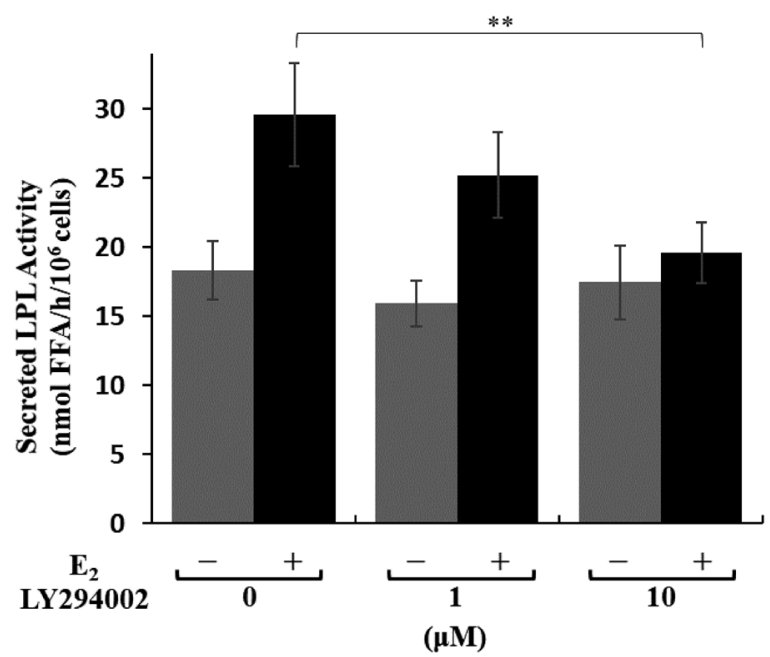

Fig. 4. Effects of PI3K Inhibitors on Stimulatory Secretion of LPL by $\mathrm{E}_{2}$

FM3A cells were incubated for $60 \mathrm{~min}$ with $10 \mathrm{nM} \mathrm{E}_{2}$ or without in presence of LY294002. The activity of LPL secreted into the medium was measured as described in Materials and Methods $(* * p<0.01)$ rapamycin (Fig. 5b).

Effects of Rictor Knock-Down on $E_{2}$-Enhanced Secretion of LPL To further investigate whether stimulatory secretion of LPL by $\mathrm{E}_{2}$ is mainly via mTORC2. Rictor is a novel binding partner, and is essential for activation of mTORC2. ${ }^{20,21)}$ Therefore, we decreased expression of Rictor by siRNA knockdown of Rictor mRNA in FM3A cells (Fig. 6a). Subsequently, when knock-down cells were incubated with $E_{2}$, the stimulatory secretion of LPL by $E_{2}$ was markedly suppressed $\left(p<0.01,10 \mathrm{nM} \mathrm{E}_{2}\right)$ (Fig. 6b).

\section{DISCUSSION}

Estrogen has important physiological functions in both females and males, and in particular, the growth and proliferation of breast cancer cells are dependent on estrogen concentration. However, the role of estrogen in breast cancer cells is not fully understood. Lipoprotein lipase is a secreted protein and a key enzyme in lipid metabolism and essential in cell growth. ${ }^{22,23)}$ Few studies have investigated the effects of estrogen on lipoprotein metabolism, particularly in the secretion and activity of LPL from breast cancer cells.

In this study, $E_{2}$ enhanced the secretion of active LPL from mouse mammary tumor FM3A cells in a dose- and time-dependent manner (Figs. 1a, c). However, the amount of LPL as protein secreted into the medium was not markedly
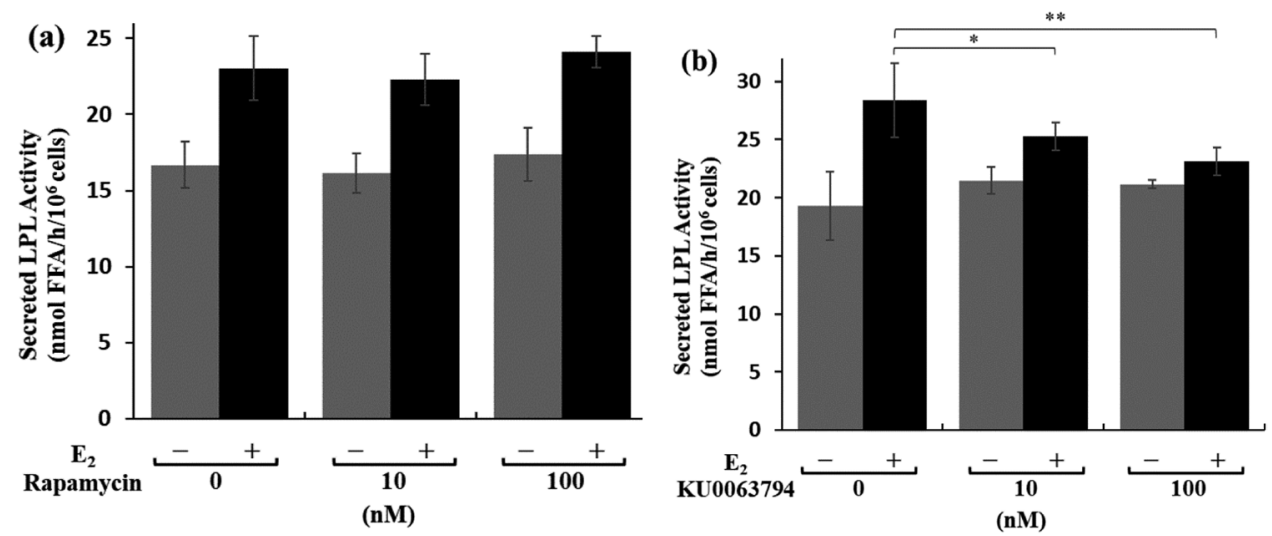

Fig. 5. Effects of mTOR Inhibitors on Stimulatory Secretion of LPL by $E_{2}$

FM3A cells were incubated for $60 \mathrm{~min}$ with $10 \mathrm{nM} \mathrm{E}_{2}$ or without in presence of rapamycin (a) and KU0063794 (b). The activity of LPL secreted into the medium was measured as described in Materials and Methods $\left(* p<0.05,{ }^{* *} p<0.01\right)$.

(a) Control siRNA Rictor siRNA

\begin{tabular}{|c|c|c|c|c|c|}
\hline 0 & 1 & 10 & 0 & 1 & 10 \\
\hline$=$ & $=$ & - & $6 x$ & 20. & wexh \\
\hline
\end{tabular}

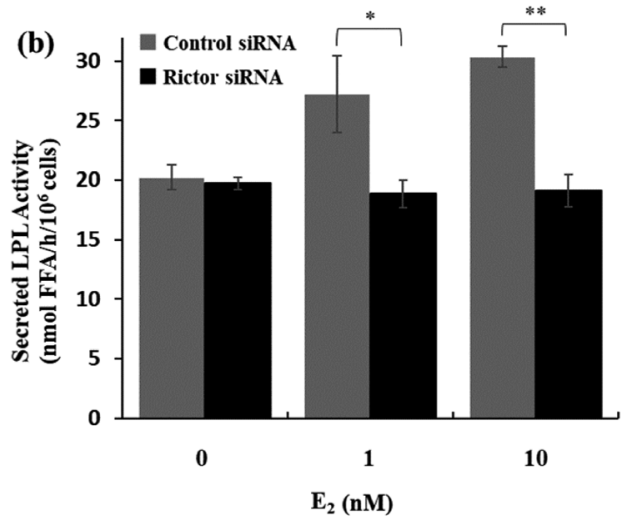

Fig. 6. Effects of Rictor Knock-Down on Stimulatory Secretion of LPL by $E_{2}$

FM3A cells were transfected with Rictor siRNA and control siRNA (a). Transfected cells were incubated for 60 min with $\mathrm{E}_{2}$ (b). The activity of LPL secreted into the medium was measured as described in Materials and Methods $(* p<0.05, * * p<0.01)$. 
increased (Figs. 1b, d). LPL is synthesized in rough endoplasmic reticulum (ER), it is modified in ER and golgi, and is then secreted as an active form. ${ }^{24)}$ It was recognized that LPL is catalytically active only as a homodimer, ${ }^{25-27)}$ and both active and inactive forms of LPL have been found. ${ }^{28)} \mathrm{A}$ recent report showed that some monomers of LPL may be enzymatically active, ${ }^{29)}$ suggesting that the increase of secreted active LPL by $E_{2}$ is not due to an increase in amount of LPL protein, but is due to an increase in LPL specific activity by the promotion of post-translational modification to increase abundance of the active form. In addition, the decrease in intracellular LPL activity and invariant protein content by $\mathrm{E}_{2}$ may be due to the preferential secretion of active LPL.

There are several reports that $\mathrm{E}_{2}$ activates the MAPK signal transduction pathway. ${ }^{18,19)}$ In our data, $E_{2}$ also elevated MAPK activity in the tumor cells (Fig. 2). The stimulatory secretion of LPL activity by $\mathrm{E}_{2}$ was suppressed by various inhibitors, except SP600125 of the MAPK subfamily (Figs. 3a, b, c, d). Therefore, we investigated changes to PI3K activity, which is also reported to be activated by $\mathrm{E}_{2} \cdot{ }^{30}$ ) The $\mathrm{E}_{2}$-enhanced secretion of LPL activity was reduced by a PI3K inhibitor, LY294002 (Fig. 4). In bladder carcinoma, an mTOR is suggested to affect the downstream regulation of PI3K transduction pathway. ${ }^{31)} \mathrm{E}_{2}$ activation of mTOR via the estrogen receptor has been observed in various cells. ${ }^{32-34)}$ An inhibitor of mTORC1 and C2, KU0063794 decreased the stimulatory secretion of LPL by $\mathrm{E}_{2}$, but an mTORC1 inhibitor, rapamycin did not (Figs. 5a, b). Finally, we determined that the stimulatory secretion of LPL by $\mathrm{E}_{2}$ was suppressed with the siRNA knock-down of Rictor in mTOR (Fig. 6b).

These results suggest that the stimulatory secretion of the more active LPL by $\mathrm{E}_{2}$ from mouse mammary tumor FM3A cells is due to the activation of MTORC2 with an association of MAPK-PI3K transduction pathway through the estrogen receptor.

Conflict of Interest The authors declare no conflict of interest.

\section{REFERENCES}

1) Ghoncheh M, Pournamdar Z, Salehiniya H. Incidence and mortality and epidemiology of breast cancer in the world. Asian Pac. J. Cancer Prev., 17 (S3), 43-46 (2016).

2) Eliassen AH, Spiegelman D, Xu X, Keefer LK, Veenstra TD, Barbieri RL, Willett WC, Hankinson SE, Ziegler RG. Urinary estrogens and estrogen metabolites and subsequent risk of breast cancer among premenopausal women. Cancer Res., 72, 696-706 (2012).

3) Sampson JN, Falk RT, Schairer C, Moore SC, Fuhrman BJ, Dallal CM, Bauer DC, Dorgan JF, Shu XO, Zheng W, Brinton LA, Gail MH, Ziegler RG, Xu X, Hoover RN, Gierach GL. Association of estrogen metabolism with breast cancer risk in different cohorts of postmenopausal women. Cancer Res., 77, 918-925 (2017).

4) Feigelson HS, Henderson BE. Estrogens and breast cancer. Carcinogenesis, 17, 2279-2284 (1996).

5) Suzuki R, Orsini N, Saji S, Key TJ, Wolk A. Body weight and incidence of breast cancer defined by estrogen and progesterone receptor status - a meta-analysis. Int. J. Cancer, 124, 698-712 (2009).

6) Key TJ, Appleby PN, Reeves GK, et al. Body mass index, serum sex hormones, and breast cancer risk in postmenopausal women. $J$. Natl. Cancer Inst., 95, 1218-1226 (2003).

7) Chu SY, Lee NC, Wingo PA, Senie RT, Greenberg RS, Peterson
HB. The relationship between body mass and breast cancer among women enrolled in the Cancer and Steroid Hormone Study. J. Clin. Epidemiol., 44, 1197-1206 (1991).

8) Kulkoyluoglu-Cotul E, Arca A, Madak-Erdogan Z. Crosstalk between estrogen signaling and breast cancer metabolism. Trends Endocrinol. Metab., 30, 25-38 (2019).

9) Gunter MJ, Xie X, Xue X, Kabat GC, Rohan TE, WassertheilSmoller S, Ho GY, Wylie-Rosett J, Greco T, Yu H, Beasley J, Strickler HD. Breast cancer risk in metabolically healthy but overweight postmenopausal women. Cancer Res., 75, 270-274 (2015).

10) Madak-Erdogan Z, Band S, Zhao YC, Smith BP, KulkoyluogluCotul E, Zuo Q, Santaliz Casiano A, Wrobel K, Rossi G, Smith RL, Kim SH, Katzenellenbogen JA, Johnson ML, Patel M, Marino N, Storniolo AMV, Flaws JA. Free fatty acids rewire cancer metabolism in obesity-associated breast cancer via estrogen receptor and mTOR signaling. Cancer Res., 79, 2494-2510 (2019).

11) Lupien LE, Bloch K, Dehairs J, Traphagen NA, Feng WW, Davis WL, Dennis T, Swinnen JV, Wells WA, Smits NC, Kuemmerle NB, Miller TW, Kinlaw WB. Endocytosis of very low-density lipoproteins: an unexpected mechanism for lipid acquisition by breast cancer cells. J. Lipid Res., 61, 205-218 (2020).

12) Wing DR, Salaman MR, Robinson DS. Clearing-factor lipase in adipose tissue. Factors influencing the increase in enzyme activity produced on incubation of tissue from starved rats in vitro. Biochem. J., 99, 648-656 (1966).

13) Enerbäck S, Semb H, Tavernier J, Bjursell G, Olivecrona T. Tissuespecific regulation of guinea pig lipoprotein lipase; effects of nutritional state and of tumor necrosis factor on mRNA levels in adipose tissue, heart and liver. Gene, 64, 97-106 (1988).

14) Davies BS, Beigneux AP, Barnes RH 2nd, Tu Y, Gin P, Weinstein MM, Nobumori C, Nyrén R, Goldberg I, Olivecrona G, Bensadoun A, Young SG, Fong LG. GPIHBP1 is responsible for the entry of lipoprotein lipase into capillaries. Cell Metab., 12, 42-52 (2010).

15) Nilsson-Ehle P, Tornqvist H, Belfrage P. Rapid determination of lipoprotein lipase activity in human adipose tissue. Clin. Chim. Acta, 42, 383-390 (1972).

16) Belfrage P, Vaughan M. Simple liquid-liquid partition system for isolation of labeled oleic acid from mixtures with glycerides. $J$. Lipid Res., 10, 341-344 (1969).

17) Ferby IM, Waga I, Sakanaka C, Kume K, Shimizu T. Wortmannin inhibits mitogen-activated protein kinase activation induced by platelet-activating factor in guinea pig neutrophils. J. Biol. Chem., 269, 30485-30488 (1994).

18) Long X, Gize EA, Nephew K, Bigsby RM. Evidence for estrogenic contamination of the MAPK inhibitor PD98059. Endocrinology, 142, 5390-5393 (2001).

19) Yue W, Wang JP, Conaway M, Masamura S, Li Y, Santen RJ. Activation of the MAPK pathway enhances sensitivity of MCF-7 breast cancer cells to the mitogenic effect of estradiol. Endocrinology, 143, 3221-3229 (2002).

20) Sarbassov DD, Ali SM, Kim DH, Guertin DA, Latek RR, Erdjument-Bromage H, Tempst P, Sabatini DM. Rictor, a novel binding partner of mTOR, defines a rapamycin-insensitive and raptor-independent pathway that regulates the cytoskeleton. Curr. Biol., 14, 1296-1302 (2004).

21) Chen X, Liu M, Tian Y, Li J, Qi Y, Zhao D, Wu Z, Huang M, Wong CCL, Wang HW, Wang J, Yang H, Xu Y. Cryo-EM structure of human mTOR complex 2. Cell Res., 28, 518-528 (2018).

22) Kuemmerle NB, Rysman E, Lombardo PS, Flanagan AJ, Lipe BC, Wells WA, Pettus JR, Froehlich HM, Memoli VA, Morganelli PM, Swinnen JV, Timmerman LA, Chaychi L, Fricano CJ, Eisenberg BL, Coleman WB, Kinlaw WB. Lipoprotein lipase links dietary fat to solid tumor cell proliferation. Mol. Cancer Ther., 10, 427-436 (2011).

23) Dong W, Gong H, Zhang G, Vuletic S, Albers J, Zhang J, Liang H, Sui Y, Zheng J. Lipoprotein lipase and phospholipid transfer 
protein overexpression in human glioma cells and their effect on cell growth, apoptosis, and migration. Acta Biochim. Biophys. Sin. (Shanghai), 49, 62-73 (2017)

24) He P-P, Jiang T, OuYang X-P, Liang Y-Q, Zou J-Q, Wang Y, Shen Q-Q, Li L, Zheng X-L. Lipoprotein lipase: biosynthesis, regulatory factors, and its role in atherosclerosis and other diseases. Clin. Chim. Acta, 480, 126-137 (2018).

25) Lookene A, Zhang L, Hultin M, Olivecrona G. Rapid subunit exchange in dimeric lipoprotein lipase and properties of the inactive monomer. J. Biol. Chem., 279, 49964-49972 (2004).

26) Peterson J, Ayyobi AF, Ma Y, Henderson H, Reina M, Deeb SS, Santamarina-Fojo S, Hayden MR, Brunzell JD. Structural and functional consequences of missense mutations in exon 5 of the lipoprotein lipase gene. J. Lipid Res., 43, 398-406 (2002).

27) Kobayashi Y, Nakajima T, Inoue I. Molecular modeling of the dimeric structure of human lipoprotein lipase and functional studies of the carboxyl-terminal domain. Eur. J. Biochem., 269, 4701-4710 (2002).

28) Bergö M, Olivecrona G, Olivecrona T. Forms of lipoprotein lipase in rat tissues: in adipose tissue the proportion of inactive lipase increases on fasting. Biochem. J., 313, 893-898 (1996).

29) Beigneux AP, Allan CM, Sandoval NP, Cho GW, Heizer PJ, Jung RS, Stanhope KL, Havel PJ, Birrane G, Meiyappan M, Gill JE 4th, Murakami M, Miyashita K, Nakajima K, Ploug M, Fong LG, Young
SG. Lipoprotein lipase is active as a monomer. Proc. Natl. Acad. Sci. U.S.A., 116, 6319-6328 (2019).

30) Garrido P, Morán J, Alonso A, González S, González C. $17 \beta$-estradiol activates glucose uptake via GLUT4 translocation and PI3K/Akt signaling pathway in MCF-7 cells. Endocrinology, 154, 1979-1989 (2013).

31) Nawroth R, Stellwagen F, Schulz WA, Stoehr R, Hartmann A, Krause BJ, Gschwend JE, Retz M. S6K1 and 4E-BP1 are independent regulated and control cellular growth in bladder cancer. PLoS ONE, 6, e27509 (2011).

32) Wang Y, Zhu L, Kuokkanen S, Pollard JW. Activation of protein synthesis in mouse uterine epithelial cells by estradiol-17 $\beta$ is mediated by a PKC-ERK1/2-mTOR signaling pathway. Proc. Natl. Acad. Sci. U.S.A., 112, E1382-E1391 (2015).

33) Zhao Y, He L, Zhang Y, Zhao J, Liu Z, Xing F, Liu M, Feng Z, $\mathrm{Li}$ W, Zhang J. Estrogen receptor alpha and beta regulate actin polymerization and spatial memory through an SRC-1/mTORC2dependent pathway in the hippocampus of female mice. J. Steroid Biochem. Mol. Biol., 174, 96-113 (2017).

34) Tao Y, Sun H, Sun H, Qiu X, Xu C, Shi C, Du J. 17ק-Estradiol activates mTOR in chondrocytes by AKT-dependent and AKT-independent signaling pathways. Int. J. Clin. Exp. Pathol., 8, 15911-15918 (2015). 